Georgia State University

ScholarWorks @ Georgia State University

\title{
Toleration by Victimized Coffeeshops in Amsterdam
}

Scott Jacques

Georgia State University, sjacques1@gsu.edu

Kim Moeller

Malmo University College, kim.moeller@mau.se

Follow this and additional works at: https://scholarworks.gsu.edu/cj_facpub

Part of the Criminology and Criminal Justice Commons

\section{Recommended Citation}

Jacques, Scott and Moeller, Kim, "Toleration by Victimized Coffeeshops in Amsterdam" (2021). CJC Publications. 28.

https://scholarworks.gsu.edu/cj_facpub/28

This Working Paper is brought to you for free and open access by the Department of Criminal Justice and Criminology at ScholarWorks @ Georgia State University. It has been accepted for inclusion in CJC Publications by an authorized administrator of ScholarWorks @ Georgia State University. For more information, please contact scholarworks@gsu.edu. 
Dutch "coffeeshops" are the world's chief example of drug control via toleration (see Leuw, 1991; Leuw and Marshall, 1994; MacCoun, 2011; MacCoun and Reuter, 1997; Reinarman, Cohen, and Kaal, 2004; Wouters and Korf, 2009). In the Netherlands, it is de jure illegal to sell cannabis, but the national government and some municipalities condone its retail distribution by coffeeshops (NMHWS, 2003; NMFA, 2008). Yet, this business is not without risk. It is de jure and de facto illegal for them to procure the supply of cannabis for resale, which is punishable by a large fine or imprisonment (Trimbos Institute, 2010; Van der Gouwe, Ehrlich, and Van Laar, 2009). They must obey a variety of regulations or be closed, for a short-term to permanently.

Additionally, coffeeshops face the threat of victimization from violence, theft, fraud, and destruction (see Jacques, 2019; Jacques et al., 2016). In this article, we examine one way they respond to crimes against them: toleration (Black, 1998). We nest our study within the literature on social control by victimized drug dealers. After outlining key concepts and prior findings, we describe the foundational elements of the present study: contextualization within Dutch coffeeshop policy; the opportunity and rational choice perspectives; and, analysis of qualitative data obtained via interviews with personnel (owners and employees) of 50 coffeeshops in Amsterdam, the Netherlands. From there, we show why and how coffeeshops tolerate victimization. We conclude with thoughts on how our findings are similar to, and different from, those in the literature on social control by drug dealers.

\section{Social Control}

At a broad level, this article contributes to the study of social control, also known as conflict management (Black, 1998; Cooney, 2009). Herein, this concept refers to social ways of handling wrongdoing. It varies qualitatively. Formal control is, by definition, exercised by governmental actors (Black, 1976). It includes arrest, prosecution, conviction, and punishment by imprisonment, execution, or other means (Cooney 2009). Informal control is the domain of non-governmental actors. They may shun offenders, demand compensation, or turn to selfhelp (Black, 1998; Cooney, 2009). Self-help is a broad concept that includes everything from violent retaliation to the theft and destruction of wrongdoers' property, to spreading gossip about them. 
Social control varies quantitatively, too. For example, formal control is more severe when an offender is executed than imprisoned; convicted than acquitted; arrested than not. The same applies to forms of informal control. Retaliation is more severe than compensation, which is more severe than avoidance (Black, 1976, 1998; Cooney, 2009). Within those forms of control, responses are more severe when more injury is sustained, more compensation is paid, or avoidance lasts longer, and so forth.

\section{Toleration as Social Control}

This article's narrower focus is toleration. Qualitatively, it is defined by the absence of the aforementioned forms of formal and informal control (Black, 1998; Cooney, 2009). To quote Black (1998: 98), "Toleration is inaction when a grievance might otherwise be handled. Although arguably not a form of conflict management at all, toleration is sometimes consciously advocated or adopted as the most effective response to deviant behavior, disagreement, or disruption." Toleration is a quantitative variable, as well:

A matter of degree, toleration is measurable by comparing what might otherwise occur under the same circumstances. When a group exacts blood vengeance for one killing but does little or nothing in response to another, its behavior in the latter is extremely tolerant. The same applies when a case of inaction might otherwise result in police intervention, arrest, or prosecution. We can also compare the degree of toleration across society and historical epochs. There is noticeable variation, for example, in reactions to drunkenness, adultery, homosexuality, and homicide. Nothing automatically attracts social control. (Black, 1998: 98-9)

Toleration is relevant to our understanding of both formal and informal control. It has theoretical importance for the very reason that when it occurs, other forms of control are absent. By explaining why toleration occurs, we expand knowledge about why other forms of conflict management do not occur (Jacques and Wright, 2008). This is only realized, however, when we conceptualize toleration as one of several forms of social control (as done above), and take strides to spell out the theoretical implications of toleration's occurrence for the others.

\section{Opportunity and Rationality}

Social control broadly, and toleration in particular, are affected by opportunity and rationality. The opportunity perspective provides a foundational logic that opens and closes the 
range of choices (Cohen and Felson, 1979; Felson and Clarke, 1998). The rationality perspective orients us to how actions' utility, or benefits minus costs, affects the decision to enact one or another (Bentham, [1823] 1988; Cornish and Clarke 1986).

To explain behavior, we must first determine what is possible. Opportunity varies. It also precedes decision-making. We look to see what can be done and, by extension, what choices are to be made. Every action hinges on the congruence of minimal elements (Cohen and Felson, 1979; Cohen, Kluegel, and Land, 1981: 508-9; Felson and Clarke, 1998; Sparks, 1982: 29-30). Without one or more of those elements, the action is impossible. For example, if a victim cannot determine the offender's identity, it is impossible to retaliate. This makes the rationality of that response a moot point; it is inconsequential because there is zero opportunity to act on it. Conversely, if the victim knows fthe offender's identity, it is possible to retaliate.

If a person is faced with two or more possible ways to act, they choose between them by weighing - consciously or subconsciously - their respective utility (Bentham, [1823] 1988; Cornish and Clarke 1986). Benefits and costs come in many forms, such as financial versus reputational. Other influences on decision-making may be in play, such as emotions or intoxication. For these reasons, rationality is said to be "bounded" (Cornish and Clarke 1986). Within those boundaries, people are assumed to act in ways that maximize utility. So, continuing with the above example, if it is possible for a victim to retaliate, they will decide whether to do so by assessing its benefits and costs versus alternative ways to manage the conflict.

\section{Opportunistic and Rational Social Control by Victimized Dealers}

Traditionally, research on social control by illicit drug dealers - or "dealers" for short focuses on violent retaliation (e.g., Anderson, 1999; Jacobs and Wright, 2006; Jacques and Allen, 2015; Topalli, Wright, and Fornango, 2002). It has two necessary conditions: a victim and offender overlap in time and space; and, the victim must have the physical capacity (e.g., not be paralyzed) to be violent (Jacques, 2010). This response's potential benefits are vengeance, resource recovery, and deterrence. The potential costs are being hurt or killed while retaliating 
or subsequently in an act of counter-retaliation. There is a formal risk, too: because violent retaliation is a criminal act, it may result in arrest, prosecution, and punishment.

Often for dealers, the rationality of violent retaliation is attributed to the lack of opportunity for them to mobilize law. The basic premise is that because dealers are involved in crime, they lack access to formal means of redress, which, in effect, makes violent retaliation a relatively rational option (Goldstein 1985; Jacques et al., 2016). This is an extension of the Hobbes' (1985 [1651]) classic theory that stateless societies have more violence (see also Cooney, 1998; Elias, 2000 [1939]; Weber, 1978 [1922]; for evidence, see Pinker, 2011).

In the literature, there is a subtle tension between whether dealers can mobilize law (i.e., a facet of opportunity) or choose not to do so (i.e., a rational decision). Some academic declarations proscribe the rule of law: "black market entrepreneurs cannot be 'victims' and therefore lack access to official means of grievance redress" (Jacobs, 2000: 1). Other statements leave the interpretation open to the reader: "The markets for illegal goods and services operate without the usual protections against fraud and violence offered by the court system" (Reuter 2009: 275).

Fact is, any dealer can mobilize law. The opportunity exists, but its rationality varies across cases. Risks are that "snitching" lead to retaliation or brings the police's attention to one's crimes (Jacques and Wright, 2013; Natapoff, 2009). Yet dealers mobilize law, probably more than you would think (Copes et al., 2011: 159; Goldstein, 1985: 501; Mohamed and Fritsvold, 2009: 145; Moskos, 2008: 100; Rosenfeld, Jacobs, and Wright, 2003). This is because legal mobilization has the same potential benefits as violent retaliation: vengeance, resource recovery, and deterrence (Jacques and Wright, 2013; Jacques and Allen, 2015).

Dealers also manage victimization with nonviolent forms of informal control (Jacques and Wright, 2008, 2011). Nonviolent retaliation is possible and practical to the extent that a victim can get near an offender's property and damage or steal it (Jacques, 2010). Another form of self-help, gossip, allows victims to get even by discrediting offenders, plus may help fellow dealers from being victimized the same way (Dickinson and Wright, 2015). Negotiation provides a means for reaching compensation and continuing a profitable business relationship, but requires the offenders' cooperation and, thus, may open the door to repeat victimization 
(Hoffer, 2006; Venkatesh, 2008). And avoidance, by limiting further interaction with the

offender, protects against further victimization, but may come at the cost of lost sales (Denton, 2001; Taylor, 2007).

\section{Opportunistic and Rational Toleration by Victimized Dealers}

To our knowledge, toleration has not been the principle focus of any study on social control by dealers. What is known about dealers' toleration of victimization is piecemeal; a digression, or logical beginning or endpoint of examinations into the others forms of conflict management, typically violent retaliation (e.g., Coomber and Maher, 2006; Jacobs, 2000; Jacobs and Wright, 2006; Jacques and Wright, 2008, 2015; Moeller and Sandberg, 2017; Taylor, 2007). Nonetheless, those findings provide a useful starting point for informing dealers' toleration of victimization.

For example, Jacobs (1999) attends to the lack of violent retaliation among street-level dealers. In the following excerpt, note the importance of opportunity and costs in the decision to forgo retaliation:

[T] he extent to which sellers could or did seek revenge was limited. Tracking down petty brigands not only is difficult, but it takes time, foresight, and planning-qualities few offenders can muster. Given their desperation for customers, the availability of the same undifferentiated product in nearby locales, and the general state of stagnating demand, a certain sense of ambivalence seemed to prevail about punishing customers they did track down. (p. 80)

A separate study of street dealers, namely that of Topalli, Wright, and Fornango (2002), focuses more so on the rationality of toleration:

A number of drug dealer/victims indicated that, in the absence of direct retaliation, the only way to recover from a robbery was simply to go back out and resume selling. ... These individuals not only were unwilling to suffer the potentially serious consequences of retaliating (i.e. counter-retaliation or arrest and incarceration), they also considered retaliation an inefficient use of time better spent hustling. ... Typically, this meant accepting robbery [victimization] as a normal cost of street-corner drug selling. ... [Or they] justified their unwillingness to engage in retaliation as sound fiscal policy. Smirk, for example, claimed that he could easily have retaliated against the assailants, but chose not to because "that shit's bad for business." (p. 346-8)

Those ideas are echoed in Jacques and Wright's (2011) research on conflict management by lower-class and middle-class dealers: 
Toleration is valuable to disputants because it maintains the status quo. Toleration takes no time or effort, nor is it illegal. Therefore, disputants may prefer to do nothing rather than exercise more costly forms of informal control. Tolerating a grievance may allow for the reparation of formerly beneficial partnerships and thereby facilitate drug trade. ... Drug traders will sometimes refrain from retaliation and other forms of popular justice for fear of subsequent retaliation, which may entail the cost of injury or theft. (p. 754-5)

In short, there is always the opportunity for toleration. An advantage (not a benefit per se) of toleration is it takes no time or effort (i.e., costs nothing in those regards), thereby making way for more beneficial actions (e.g., continuing to sell) (Jacobs, 1999). Unlike mobilizing police or retaliating, toleration does not risk bringing attention to one's illegal activities or escalating the conflict (Jacques and Wright, 2015; Topalli, Wright, and Fornango, 2002). On the other hand, toleration has no deterrent or retributive effect. It does not provide a direct way to recover lost resources. Yet like negotiation and unlike avoidance, toleration helps to keep a profitable relationship going (Jacques and Wright, 2011).

\section{The Present Study}

\section{Quasi-Illegal Coffeeshops}

Not all dealers are engaged in a business that is fully illegal. "Quasi-illegal" or "semiillegal" dealers are on the rise. In the United States, federal law prohibits cannabis distribution, yet some states have reduced criminal sanctions or even legalized retail sales. Other nations have decriminalized cannabis sales, including Switzerland (Killias et al., 2011), Portugal (Félix and Portugal, 2017), England and Wales (Brewster, 2017), Norway (Bretteville-Jensen and Bramness, 2019), and Denmark (Moeller, 2020). The Netherlands is the oldest and most famous example (Kleiman, Caulkins and Hawken, 2011).

Despite the influx of quasi-illegal dealers to the worldwide drug scene, research remains predominantly focused on how fully-illegal dealers respond to victimization. Largely unknown is whether and why these groups differ in conflict management. To address that lacuna, the present study examines toleration of victimization by coffeeshops in Amsterdam, the Netherlands. Their purchase of cannabis supplies is de jure and de facto illegal. Also, their retaillevel sales are de jure illegal, yet formally tolerated under certain conditions: They are 
prohibited from distributing more than 5 grams per day to an adult (i.e., person who is 18 years of age or older) (NMFA, 2008; NMHWS, 2003). The rules also prohibit minors, hard drugs, or more than 500 grams of cannabis on the premises. Nor can coffeeshops advertise or be a source of a nuisance.

The rules are actively enforced and dictate much of the day-to-day activities within coffeeshops (Jacques, 2019). The government looks for violations, among other ways, by requiring the police to randomly search each coffeeshop twice annually, at least (Trimbos Institute, 2010). Violations are punishable by short-term to permanent closure. Criminal prosecution is on the table. At the time of data collection, described below, the maximum penalty for possession, cultivation, sale, transport, and production of cannabis for commercial purposes was 6 years imprisonment and/or a fine of $€ 67,000$ (NMFA, 2008).

\section{Social Control by Victimized Coffeeshops}

Like any actor, coffeeshops can respond formally or informally to victimization. They mobilize law, retaliate against or gossip on, negotiate with, or "cut-off" the offender. Or, they do nothing; that is, tolerate the offense. Prior research on social control by victimized coffeeshops is sparse. Only two works, to our knowledge, focus on social control by victimized coffeeshops. We will directly build on them in the present study.

Jacques and colleagues (2016) compared how coffeeshops to bars and street dealers. Bars sell a drug (alcohol) that is fully legal, whereas street dealers sell various drugs (e.g., cocaine, heroin, ecstasy) that are fully prohibited. A goal of their study was to determine if the illegality of a victim's businesses affected their likelihood of responding formally or informally. They found mixed support for that hypothesis: Coffeeshops responded similarly to bars, which were more likely than street dealers to mobilize police, less likely to violently retaliate, and less likely to tolerate. That article left much unexamined and unexplained. Its limitations include no qualitative analysis of why coffeeshop personnel responded to victimization in a particular way.

In a prior article, we began to address the above study's limitations by exploring coffeeshops' qualitative reasons for mobilizing police in response to victimization (Authors XXXX). Personnel weighed whether police officers would be willing and able to help; two, and relatedly, the crime's seriousness and its conduciveness to formal investigation; three, if a 
written police report could be used to "write-off" the loss in tax filings or to make an insurance claim; and, four, whether mobilization would lead the police to see the coffeeshop as less respectable or to discover a rule violation. Those findings show that due to their quasi-illegal status, victimized coffeeshops' motivations for formal control are somewhat, on the one hand, like those of fully-illegal dealers (e.g., the fourth motive) and, on the other hand, like those of fully-legal ones (e.g., the third motive), as well as that some motivations (e.g., the first and second) cut across the spectrum of legal statuses.

Our prior study has logical implications for explaining toleration, given its inverse relationship with police mobilization. Therein, personnel's explanations for mobilizing police amount to explanations for not tolerating, and vice versa. A good example is Hassan's toleration of a $€ 400$ theft from the register. He did not call the police because "[the thief] was gone. If you call them they are going to see the camera and that's it. They are not going to do shit, believe me. It's going to get reported, that's the only thing [that will result]. It's only giving me extra work, extra headache for nothing" (Authors XXXX: 5). The crime was relatively serious, but he figured the police would be unwilling or unable to do much about it, owing to the difficultly of investigating, and he was unaware that a written police report had tax or insurance benefits. Ergo, Hassan perceived the costs of mobilizing police as outweighed by its potential benefits, making toleration the more attractive option.

\section{Data and Methods}

Whereas our prior article analyzed coffeeshop personnel's reasons for mobilizing police, the present study focuses on their reasons for tolerating victimization. It is based on qualitative data collected by [name of coauthor], here forward referred to as "the fieldworker," during interviews with personnel of 50 coffeeshops in and around Amsterdam's Red Light District. The area is about one square mile in size, and a popular tourism spot because of its history, architecture, and, not least, deviant attractions - including coffeeshops.

An initial step in the research was to create a population list of coffeeshops in the study locale. To do so, the fieldworker walked every street segment in fall 2008 , recording the names and addresses of every coffeeshop. He verified the list's accuracy and completeness by 
comparing it to results on Google Maps and the Amsterdam Coffee Shop Directory (coffeeshop.freeuk.com/Map.html). The result of that process was a list of 84 coffeeshops.

The fieldworker conducted interviews and made observations from September 2008 to May 2010, with follow-up visits in the summers of 2011 and 2016. The present study focuses on the interview data, as our focus is on personnel's explanations for tolerating victimization. Before recruiting personnel of a coffeeshop, he mailed it a letter. It described the study and requested participation, with one side of the page written in Dutch, the other English. Then he visited each coffeeshop to ask for an interview. On arrival, he introduced himself, provided his business card, and quickly described the study's purpose and methods, including that respondents would be remunerated with $€ 50$. The stated preference was to interview higherthan lower-ranking personnel, but, at a minimum, the person must have owned or worked at the coffeeshop for 6 months or more.

The interviewed personnel are $64 \%$ male, with an average age of 34 , of whom $70 \%$ identified as White, $6 \%$ Black, and $24 \%$ other. Also, $40 \%$ immigrated to the Netherlands; $10 \%$ were married; $26 \%$ graduated from secondary school; and, $56 \%$ and $30 \%$ reported, respectively, daily use of cannabis and alcohol. Participants also provided data on the traits of fellowpersonnel at their coffeeshop. On average, $67 \%$ are male, $81 \%$ White, $47 \%$ immigrants, and $15 \%$ married. At the average coffeeshop, there is one owner, one manager, five "dealers" who focus on cannabis sales but may also serve food and drink, two "servers" who focus on food and drink, a "runner" who is responsible for stocking cannabis, and perhaps one other person (e.g., dedicated cleaner or doorman).

The goal of interview was to obtain data about coffeeshops' prevention of, experience with, and responses to victimization. A semi-structured interview protocol provided consistency in coverage while permitted unplanned follow-up questions. Naturally, some participants may have distorted the "truth," intentionally or not (Presser and Sandberg 2015; Bernasco 2010). To address this concern, the fieldworker asked clarifying, promised confidentiality, and made participants aware of their rights as a research participant. The study was approved by the fieldworkers' Institutional Review Board. Conversations were in English because the fieldworker is only fluent in it, but this did not stop anyone from participating. All recruited personnel were 
fluent in English, the most commonly spoken language in the study area's coffeeshops and other tourist attractions.

Interviews lasted an hour to two, were audio-recorded, and transcribed verbatim. Eight of the 50 interviews could not be transcribed, as 7 personnel declined to be recorded and another interview took place in a loud environment. The fieldworker took detailed notes during those interviews. For analysis, we used a qualitative software package, NVivo. First, files were coded with identification tags corresponding to relevant research issues. The tags were initially broad, such as "Social Control" and then, within that node, "Toleration." Subsequently, we sifted through the data to create narrower distinctions. The emergent categories were how and why personnel tolerated victimization. Our final step was detailed analysis of variance across cases, which led to our findings, presented below.

\section{Toleration by Victimized Coffeeshops}

\section{Opportunity and Toleration}

As to be expected, personnel commonly tolerated property crimes of low seriousness. An example is graffiti on the exterior of coffeeshops. Unanimously, coffeeshops did nothing about these offenses, other than cover them up. "We paint over it," to quote James. Responses in the same vein were "painted it" (Gwen), "just try to clean it a little bit" (Mike), "the clearer repaints it" (Jens), "[the maintenance man] has to clean that shit" (Victor), and "we have a service that I can call and they come to clean it" (Anna). Max put it this way: "You just get it off and don't worry about it. I think that's the way to do business."

Graffiti was a more common problem inside coffeeshops. Patrons would add words and images to tables, seats, and other places by carving them out or penning them on. Lizzie described how she responded to writing on a table, which was made with a large black marker: "I tried to clean it, but you can't always get it all off so you have to wait [until someone can come to fix it professionally]. I think the tables are covered in some sort of epoxy. You have to pay someone to do it. That takes time. You have to buy the epoxy and sanding stuff."

Vandalism was most rampant in bathrooms, presumably due to the lack of surveillance therein. When personnel were asked how they handled bathroom vandalism, their typical 
responses amounted to "nothing" (Jasper). At most, coffeeshops would semi-regularly "paint it over" (Hassan). Referring to "Cosa Nostra" in big letters on the bathroom wall, Gwen said the "cleaner cleaned it." Dean explained that for graffiti in his coffeeshop's bathroom, the stall (i.e. partition) "is metal, [so] you have to use special stuff to clean it."

Another common, minor crime in coffeeshops was the unseen theft of low value items. Especially for small things, it is challenging for personnel to keep an eye on, and thereby stop, them from going missing. Moreover, it is difficult to quickly identify when and with who they have gone. The theft of low value items are ripe for toleration, especially when coupled with restraints on surveillance. A case in point is how personnel become cognizant of, and responded to, stolen "grinders." These tools are about the size of macarons, and used to cut marijuana into smaller pieces suitable for rolling into a joint or packing into a pipe. Olivia observed: "It is always afterwards [they are gone] that I think, 'Oh shit, someone has taken the grinder.'" Stefan explained: "You never notice [immediately] that [they are stolen] because you lend them out and then forgot or whatever, and then you're like 'Oh, the grinder's gone.' You always realize it later, of course."

In Luca's coffeeshop were miniature, swing-top, metal trashcans. Their purpose was to keep the place tidy, but they were attractive targets to some thieves. Asked how they handled these victimizations, he stated: “We don't see it happen, so we have to tolerate it. If I see them I would tell them [not to], but I never see them. [We] just buy a new one." Elias' responded likewise after potted plants were stolen from the patio: "We just bought new ones."

Vandalism and minor thefts were as common as they were tolerated. Yet this inaction to victimization is not fully explained by the crime's seriousness. Rather, a factor that increased the crimes' frequency - a lack of surveillance - also explains why they were tolerated. Of any place in coffeeshops, for example, the least watched were bathrooms. Rules of comportment dictated it was open the opportunity for vandalism therein than apply panoptic principles to lavatories. By extension, bathroom vandalism was only discovered after the fact.

Without identifying a victimizer, it is impossible for victims to respond with retaliation, negotiation, or avoidance. At the heart of rational choice is weighing the utility of options. Yet if there is only one option, its utility is inconsequential. This was often conveyed by personnel 
when explaining their responses to graffiti and minor theft: "There is nothing I can do about it [graffiti carved into table]. No idea who it was" (Gwen); "By the time we realize [the glasses are stolen], they have gone" (Joseph); "You can't do anything about it [stolen ashtrays]" (Ruben).

\section{Rationality and Toleration}

However, in the above cases, toleration is not the only option for social control. In any circumstance, victimized coffeeshops can call the police to report a problem. Thus, what explains toleration is not a total lack of alternatives. It does not appear that the personnel gave any real thought to handling those crimes by involving the police. They spoke about tolerating them in a way that reflects Geertz's (1983) notion of common sense. Personnel assumed that police would be unwilling and unable to help; saw the crimes as minor and unconducive to investigation; and, did not consider them worth "writing-off" in tax filings or worthy of an insurance claim (see Authors, XXXX). Also, it was possible that by involving the police in a problem, personnel would do damage to their coffeeshop's reputation or inadvertently bring attention to a rule violation (ibid.). Thus, personnel responded to the above victimizations by, at most, proverbially or literally painting over the problem.

Toleration does occur in more serious circumstances. Rationally speaking, this can be advantageous by allowing business to carry on, preventing a conflict from escalating. An example is how personnel responded to customers who attempted to pay with counterfeit bills. Though legally required to confiscate fakes and make a police report, personnel sometimes took a more passive approach. "I don't accept the money," said Kamila, "I return the money to the customer and ask for some different one [bill]." The fieldworker asked her, "And so this is never reported to the police or anything, you just give them the bill back and ask them to go?" She responded, "Yes, because it is not my problem at this moment."

Also evident in the above case is that victims tolerate offenses by known offenders. Linda recounted when an employee stole $€ 150$ on his last day at work. Asked how the coffeeshop's manager handled it, she answered, "Except for being pissed, I don't think much." Emma fell victim to a thief who ran off with a bag of marijuana. She could have chased after, but explained: "I am not going to run after somebody for a bag of weed, no way." After 
someone suddenly sprinted away with a bag of marijuana before paying, Hanna's reaction was, “'What' [just happened?]' And then I ran after him but he ran away [too far] already. Outside the door [is how far I got], not far." Jana was working one day when someone paid with half of a €5 bill, literally: "I picked it up and he was already gone. I was like, 'Hey!' and there was a big group [of customers that] just walked in so I could not [leave]. When I got out of the door he was already at the end [of the block], and I did not want to leave my shop alone."

The utility of toleration for moving on, versus making things worse, is seen in personnel's responses to violent victimization. James had an ongoing problem with a homeless individual. One of the recent cases was an attempted assault. A glass bottle had been thrown at him, with the intention of causing bodily harm. Instead of respond in kind, James had come to believe that the best response was to do nothing:

Nothing, because over the years it has caused me more aggravation getting wound up over him. You can say, "I have had enough of this", and try to do something about it but he has 24 hours being insane and taking all his vengeance on the world out on one person and he has a lot more effort to put into having fights. So yeah, I just really try to ignore it as much as possible because it really drains me of energy. You have to turn the other cheek. So I just decided to leave it. It is easier to just ignore it than get involved in it, because it just escalates and escalates.

Another example of tolerating violence was narrated by Selma. The story began when "two or three kilos" of cannabis were robbed from the coffeeshop owners. Asked about how they handled the situation, she responded: "I think nothing. I don't think they went after them, no." Asked if she knows why not, she said, "I think it was impossible because they were Romanian, and they come here with a car from Romania to buy this stuff to go back, and you can never find them again. How would you find them? I think it is impossible." It may have been impossible to find the robbers, but this did not make toleration the only option. The owners could have reported the crime to the police. We did not interview the owners, so we do not know their motives. Yet it is easy to imagine that they did not want to involve "the law" in a victimization that sprang from a fully-illegal drug deal gone wrong. 


\section{Discussion}

Victimization is an ever-present risk for coffeeshops. They lose money when robbed, stolen from, or defrauded. They spend money to repair the damage of vandalism. Personnel can respond formally or informally. This article examined personnel's toleration of crimes against their coffeeshops. We did so by analyzing qualitative data obtained during interviews with personnel of 50 coffeeshops in Amsterdam. Our focus was on the effect of opportunity and rational factors. Now, in this section, we specify how our findings are similar to, and different from, those in the literature on social control by dealers. In doing so, we explicate how coffeeshops' quasi-illegal status affected their toleration, the theoretical implications, and considerations for future research.

First, we found that personnel were apt to tolerate minor victimizations, such as graffiti and the theft of low value items. A lack of surveillance helps to explain this non-response. Often, by the time victims had realized they were victimized, the perpetrators were gone and their identities unknown. At that point, personnel had no opportunity to retaliate, seek compensation, or ban the offenders. This left two options for social control: mobilize law or do nothing. In line with findings in or prior article (Authors, XXXX), personnel deemed it irrational to mobilize police for those crimes. Toleration prevailed. Theoretically, the implication is that victims' knowledge of offenders' identity varies inversely with toleration (i.e., as the former increases, the latter decreases) and, conversely, directly with active forms of social control legal mobilization, self-help, negotiation, and avoidance.

Personnel could have done more to expand the options for social control (i.e., increase the range of alternatives). As a reactive measure, for example, personnel could have regularly inspected bathrooms for fresh marks. If found, personnel could then retaliate or, more likely, demand compensation from the culprit or remove them. In a world without limits, that would make more sense. Yet there are rational limits on investigation, and it may be more rational to act in other ways, as explained below.

Our second finding shows that toleration is not wholly attributable to seriousness or limited options for social control. Toleration has no direct benefits or direct costs. Its rationality stems from costing less than alternatives. It involves nothing and, therefore, takes no time and 
effort. This has two advantages: it frees time and effort to be expended on more important activities, such as selling cannabis; and, it does not escalate a conflict and risk making a problem bigger. In our data, this was evident in minor crimes and serious victimizations (Authors XXXX). To an extent, victimization was accepted as a cost of business. Theoretically, the implication is that the profitability of freed time and effort varies directly with toleration (i.e., as the former increases, the latter increases) and, in the opposite direction, inversely with active forms of social control.

Those findings are evident in prior research on fully-illegal dealers (Jacobs, 1999; Jacques and Wright, 2011, 2015; Topalli, Wright, and Fornango, 2002). So far as we can tell, fully-illegal and quasi-illegal dealers have the same motivations for toleration. Presumably, those motivations are not unique to those groups, but also apply to sellers of fully legally substances (e.g., bars, liquor stores) and actors more broadly. A distinct matter is whether drug sellers of differing legalities use toleration at the same rate. Consider, for instance, cases in which it is impossible or impractical to identity and track-down offenders, leaving victims with the choice between toleration and legal mobilization. In theory, it is riskiest for fully-illegal dealers to call the police and, thus, they should be more likely to tolerate victimizations than, say, coffeeshops. Only one quantitative study has addressed that possibility, which found support for the idea (Jacques et al., 2016). Yet, by the same reasoning, coffeeshops should be more likely to tolerate victimizations than are bars, which was not evident in that study's data. At least in the Dutch context, coffeeshops' responses to victimization appear more like those of bars than street dealers (ibid.). In and outside Amsterdam and the Netherlands, more quantitative research is needed on the rates at which dealers of differing legal statuses - fullyillegal, quasi-illegal, and fully legal - respond to victimization in various ways.

A third finding concerns how coffeeshops tolerate victimization: social inaction coupled, sometimes, with repair or replacement of damaged or stolen goods. Prior literature discusses the replacement of stolen money and drugs (Jacobs, 1999; Topalli, Wright, and Fornango, 2002), but not, to our knowledge, other items. In coffeeshops, however, toleration of a victimization was often combined with "paint[ing] over it" (James), "clean[ing] it a little bit" (Mike), or otherwise "get[ting] it off" (Max). And when something of necessity is stolen from coffeeshops (e.g., 
trashcans, ashtrays, glasses), they "bought new ones" (Elias). Possibly, the literature's lack of attention to repair and replacement is attributable to the prior focus on fully-illegal dealers.

We state our logic as a series of theoretical statements to test, expand, or refine in future research: (1) As dealers' business becomes more legal (e.g., changes from fully- to quasi-illegal), they are more likely to sell out of a public, physical store that they rent or own. This is rational to the extent it increases the opportunity for potential customers to become aware of, visit, and purchase from sellers, without the risk of legal trouble. (2) Dealers who sell from such a locale are more likely to be the victim of vandalism and theft - specifically of non-drug, non-cash items - perpetrated by an unidentified offender. This assumes that by selling in a public, physical store, there is more opportunity for dealers to interact with unknown persons; unknown persons are more likely to commit offenses (Cooney, 2006; Jacques and Wright, 2015); and, there is more opportunity to vandalize and steal such items in a public, physical store. (3) Vandalism and minor theft - specifically of non-drug, non-cash items - are more likely to be handled with repair or replacement than other victimizations. We are least confident in the validity of that assertion. Regarding theft, it is rational to replace low value items because there is little cost in doing so, but, for that very reason, it may not be imperative to replace them. However, if we hold constant an item's functional importance, it makes sense that it is more likely to be replaced, more quickly, if it costs less. The rationality of repairing property damage is more complex. If someone breaks an exterior window, there is good reason to immediately repair it; not doing so risks further victimization, among other problems. Conversely, writing on a bathroom wall is less imperative to fix. Yet by not addressing the problem sooner than later, the problem may be worsened.

In the criminological literature, the body of work mostly closely associated with repair and prevention is that on order-maintenance, or "broken windows," policing (Kelling and Wilson, 1982; Kelling and Coles, 1997). The theory is that in any given place (e.g., unique address, street block or neighborhood), onlookers perceive its physical disorder as inversely related to its control; thus, offenders' see the place as a less risky place to offend; and, therefore, more crime occurs there. In other words, a clean, unblemished environment serves as a deterrent. The practical implication is that to reduce crime at a place, its physical disorder should be minimized. That effect was not Jack's motivation for cleaning bathroom vandalism, but it become apparent: 
The toilet gets tagged [graffiti on it] a bit. We let it build up and I decorated it three months ago, and it hasn't happened since. That was the first time I decorated it in a couple of years and it was fairly heavily covered in stickers and tags and shit like that. Since I decorated, I think there has been one put up, so say once in three months. It was covered; it was hard to tell the timescale of it with something happening every week probably [in the preceding nine months].

This finding suggests that future research should explore how dealers' (non-)repair of vandalism, and plausibly their (non-)replacement of stolen items, affects their future odds of victimization.

\section{References}

Anderson, Elijah. 1999. Code of the street: Decency, violence, and the moral life of the inner city. New York: W.W. Norton \& Company.

Authors. XXXX. Anonymized Reference.

Bentham, Jeremy. [1823] 1988. The principles of morals and legislation. Amherst, NY:

Prometheus Books.

Black, Donald. 1976. The behavior of law. New York: Academic Press.

Black, Donald. 1980. The manners and customs of the police. New York: Academic Press.

Black, Donald. 1998. The social structure of right and wrong, rev. ed. San Diego, CA: Academic Press.

Bretteville-Jensen A L and Bramness J G (eds.) (2019) Cannabisboka. Oslo: Universitetsforlaget.

Brewster D (2017) Culture (s) of control: Political dynamics in cannabis policy in England \& Wales and the Netherlands. European Journal of Criminology 14(5): 566-585.

Cohen, Lawrence, and Marcus Felson. 1979. Social change and crime rate trends: a routine activity approach. American Sociological Review 44:588-608.

Cohen, L., Kluegel, J. R., and Land, K. C. (1981). Social Inequality and Predatory Criminal Victimization: An Exposition and Test of a Formal Theory. American Sociological Review, $465,505-524$.

Coomber, Ross, and Lisa Maher. 2006. Street-Level Drug Market Activity in Sydney's Primary Heroin Markets: Organization, Adulteration Practices, Pricing, Marketing and Violence." Journal of Drug Issues 36:719-753. 
Cooney, M. (1998). Warriors and Peacemakers: How Third Parties Shape Violence. New York: New York University Press.

Cooney, Mark. 2006. The Criminological Potential of Pure Sociology. Crime, Law and Social Change 46:51-63.

Cooney, Mark. 2009. Is Killing Wrong? A Study in Pure Sociology. Charlottesville, VA: University of Virginia Press.

Copes, Heith, Rod K. Brunson, Craig J. Forsyth, and Heather White. 2011. Leaving no stone unturned: Exploring responses to and consequences of failed crack-for-car transactions. Journal of Drug Issues 41: 151-174.

Cornish, Derek B., Ronald V. Clarke (eds). 1986. The reasoning criminal. New York: Springer.

Denton, Barbara. 2001. Dealing: Women in the Drug Economy. Sydney, AU: University of New South Wales Press Ltd.

Dickinson, Timothy, and Richard Wright. 2015. Gossip, Decision-Making, and Deterrence in Drug Markets. British Journal of Criminology 55:1263-1281.

Elias, Norbert. [1939] 2000. The civilizing process: Sociogenetic and psychogenetic investigations. Malden, MA: Blackwell Publishing.

Félix, Sónia, and Pedro Portugal. 2017. "Drug decriminalization and the price of illicit drugs." International Journal of Drug Policy 39: 121-129.

Felson, Marcus, and Ronald Clarke. 1998. Opportunity Makes the Thief. Crime Prevention and Detection Series, paper 98. London, UK: Home Office.

Goldstein, Paul. J. 1985. The drugs/violence nexus: A tripartite conceptual framework. Journal of Drug Issues 15:493-506.

Hobbes, Thomas. [1651] 1985. Leviathan. New York: Penguin Classics.

Hoffer, Lee D. 2006. Junkie Business: The Evolution and Operation of a Heroin Dealing Network. Belmont, CA: Wadsworth Publishing.

Jacobs, Bruce A. 1999. Dealing crack: The social world of streetcorner selling. Boston, MA: Northeastern University Press.

Jacobs, Bruce A. 2000. Robbing drug dealers: Violence beyond the law. New York: Aldine de Gruyter. 
Jacobs, Bruce A. and Richard Wright. 2006. Street justice: Retaliation in the criminal underworld. New York: Cambridge University Press.

Jacques, Scott. 2010. The Necessary Conditions for Retaliation: Toward a Theory of Non-Violent and Violent Forms in Drug Markets. Justice Quarterly 27:186-205.

Jacques, Scott. 2019. Grey Area: Regulating Amsterdam's Coffeeshops. UCL Press.

Jacques, Scott, and Richard Wright. 2008. The Relevance of Peace to Studies of Drug Market Violence. Criminology 46:221-253.

Jacques, Scott, and Richard Wright. 2011. Informal Control and Illicit Drug Trade. Criminology 49:726-765.

Jacques, Scott, and Richard Wright. 2013. How Victimized Drug Traders Mobilize Police. Journal of Contemporary Ethnography 42:545-575.

Jacques, Scott, and Richard Wright. 2015. Code of the Suburb: Inside the World of Young Middle-Class Drug Dealers. University of Chicago Press.

Jacques, Scott, Richard Rosenfeld, Richard Wright, and Frank van Gemert. 2016. Effects of Prohibition and Decriminalization on Drug Market Conflict: Comparing Street Dealers, Coffeeshops, and Cafés in Amsterdam. Criminology \& Public Policy 15:843-875.

Kelling, George L., and Catherine M. Coles. 1997. Fixing Broken Windows: Restoring Order and Reducing Crime in Our Communities. New York: Simon and Schuster.

Kelling, George L., and James Q. Wilson. 1982. Broken Windows: The Police and Neighborhood Safety. The Atlantic. Retrieved December 20, 2020, from https://www.theatlantic.com/magazine/archive/1982/03/broken-windows/304465/.

Killias, M, Isenring G L, Gillieron G and Vuille J (2011) Do drug policies affect cannabis markets? A natural experiment in Switzerland, 2000-10. European Journal of Criminology 8(3): 171-186.

Kleiman, Mark AR, Jonathan P. Caulkins, and Angela Hawken. 2011. Drugs and Drug Policy: What Everyone Needs to Know. New York: Oxford University Press.

Leuw, Ed. 1991. Drugs and drug policy in the Netherlands. Crime and Justice 14:229-276.

Leuw, Ed and Haen Marshall (eds.). 1994. Between Prohibition \& legislation: the Dutch experiment in drug policy. Amsterdam, NL: Kugler. 
MacCoun, Robert J. and Peter Reuter. 1997. Interpreting Dutch cannabis policy: Reasoning by analogy in the legalization debate. Science 278(5335):47-52.

MacCoun, Robert J. 2011. What can we learn from the Dutch cannabis coffeeshop system? Addiction 106:1899-1910.

Moeller Kim. 2020. Enforcement intensity in Danish drug control, 1996-2017. European Journal on Criminal Policy and Research: 1-16. https://doi.org/10.1007/s10610-020-09437-4

Moeller, Kim, and Sveinung Sandberg. 2017. "Debts and threats: Managing inability to repay credits in illicit drug distribution." Justice Quarterly 34: 272-296.

Mohamed, A. Rafik, and Erik D. Fritsvold. 2010. Dorm room dealers: Drugs and the privileges of race and class. Boulder, CO: Lynne Rienner.

Moskos, Peter. 2008. Cop in the hood: My year policing Baltimore's Eastern District. Princeton, NJ: Princeton University Press.

Natapoff, Alexandra. 2009. Snitching: Criminal Informants and the Erosion of American Justice. New York: NYU Press.

Netherlands Ministry of Foreign Affairs (NMFA). 2008. Q \& A Drugs. The Hague, NL: Ministry of Foreign Affairs.

Netherlands Ministry of Health, Welfare and Sport (NMHWS). 2003. Drug policy in the Netherlands: Basic principles and enforcement in practice. The Hague, NL: NMHWS.

Pinker, Steven. 2011. The better angels of our nature: Why violence has declined. New York: Viking.

Reinarman, Craig, Peter D. A. Cohen, and Hendrien L. Kaal. 2004. The limited relevance of drug policy: Cannabis in Amsterdam and San Francisco. American Journal of Public Health 94:836-842.

Reuter, Peter. 2009. Systemic violence in drug markets. Crime, Law, \& Social Change 52:275284.

Rosenfeld, Richard, Bruce Jacobs, and Richard Wright. 2003. Snitching and the code of the street. British Journal of Criminology 43:291-309.

Sparks, R. F. 1982. Research on Victims of Crime: Accomplishments, Issues, and New Directions. Rockville: National Institute of Mental Health. 
Taylor, Angela P. 2007. How drug dealers settle disputes: Violent and nonviolent outcomes. Monsey, NY: Criminal Justice Press.

Topalli, Volkan, Richard Wright, and Robert Fornango. 2002. Drug dealers, robbery and retaliation: vulnerability, deterrence and the contagion of violence. British Journal of Criminology 42:337-351.

Trimbos Institute. 2010. Netherlands national drug monitor annual report 2009. Utrecht, NL: Trimbos Institute.

Van Der Gouwe, D., E. Ehrlich, and M. W. van Laar. 2009. Drug policies in the Netherlands. Utrecht, NL: Trimbos Institute.

Venkatesh, Sudhir. 2008. Gang Leader for a Day: A Rogue Sociologist Takes to the Streets. New York: Penguin.

Weber, Max [1922] 1978. Economy and society: An outline of interpretative sociology. Berkeley and Los Angeles, CA: University of California Press.

Wouters, Marije, and Dirk J. Korf. 2009. Access to licensed cannabis supply and the separation of markets policy in the Netherlands. Journal of Drug Issues 39:627-651. 